\title{
Babesia spp. and Ehrlichia chaffeensis infection in Dogs from Southeastern Bahia, Brazil
}

\author{
Tatiani Vitor Harvey', Jéssica Fontes Veloso', Milane Ribeiro Santos' ${ }^{1}$, Maíra Siles Assunção², Leonardo Sauer², \\ Paula Elisa Brandão Guedes', Thais Nascimento de Andrade Oliveira', George Rego Albuquerque ${ }^{3}$, \\ Fabiana Lessa Silva ${ }^{3}$, Alexandre Dias Munhoz ${ }^{3}$ \& Renata Santiago Alberto Carlos ${ }^{3}$
}

\begin{abstract}
Background: Tickborne diseases are frequent in tropical countries such as Brazil. Protozoa of the Babesia genus and bacteria of the Ehrlichia genus spread throughout the country with high prevalences in urban and rural areas, causing clinical or subclinical diseases in dogs. This study aimed to investigate the prevalence of infection from Babesia spp. and Ehrlichia chaffeensis in the dog population in the municipality of Ituberá, Bahia, Brazil, and to verify the risk factors associated with the infections.

Materials, Methods \& Results: A cross-sectional study was conducted, consisting of the following procedures: clinical examination and blood samples collection from $380 \mathrm{dogs}$ and application of a structure questionnaire to dog owners to collect epidemiological data. All dogs were evaluated for the presence of ticks and clinical signs associated with the infections. Blood samples were collected and tested for Babesia spp. through capillary blood smears, indirect immunofluorescence assays (IFAT), and polymerase chain reaction (PCR); all the samples were also tested for $E$. chaffeensis through nested PCR. Intra-erythrocyte piroplasms were visualized in the blood smears of two animals $(2 / 380 ; 0.5 \%)$ in the cytology exams. Anti- $B$. canis antibodies were detected in 140/380 (36.8\%) dogs, at 1:40 dilution. By PCR, 147/380 (38.7\%) dogs tested positive for infection by Babesia sp., but no animal was infected by E. chaffeensis. Only 115/380 dogs (30.3\%) were infested by ticks. In total, 223/380 dogs (58.7\%) were found infected by Babesia spp. No clinical signs were it found to be significant for the infection. The infected $(\mathrm{Ht}=40 \%)$ and uninfected dogs' $(\mathrm{Ht}=39 \%)$ hematocrit averages were not found to significantly differ $(P=0.47)$. No hematological changes were found to be significant for the disease. The evaluated variables sex, habitat (urban or rural), exposure to other dogs, age, and infestation by ticks were not found to be risk factors. The condition of semirestriction of $175 / 223(78.4 \%)$ dogs was found as a risk factor for the infection $(P=0.01$; OR $=1.75$; IC 95\% $=1.10-2.78)$. Discussion: The low detection from blood smears was inferior to the lowest prevalences found in Brazil. On the other hand, the high seroprevalence rate by IFAT observed in this study was found in other Brazilian states. The low infection prevalence in the cytologic analysis associated with high seroprevalence are characteristics of chronic or subclinical infections. The high seroprevalence rates may also indicate chronicity and/or subclinical disease when associated with low parasitemia and may also be indicated by the low title variation observed. In this study, some dogs that tested positive for Babesia by serology tested negative in the PCR, which suggests a previously exposure to this pathogen and maintenance of detectable levels of antibodies, or that they were subclinical or chronic carriers of the infection. The equal hematocrit averages of dogs either carrying or not the disease suggests that the infected animals, especially the seemingly healthy dogs, are subclinical or chronic carriers, either asymptomatic or otherwise, that are adapted to the disease, which may contribute to the agent remaining in this population. The fact that no clinical sign of hematological change was significant for the infection may demonstrate the low pathogenicity of this agent in the evaluated population. The semi-restricted condition of the dogs as a risk factor is probably due to the increased exposure of these animals to canine babesiosis vectors during their movement through different neighborhood areas and villages in the municipality. The combination of diagnostic methods is important to identify the infection and determine its prevalence in epidemiological studies. Also, PCR was fundamental in this study, to identify the infection in asymptomatic dogs.
\end{abstract}

Keywords: babesiosis, Ehrlichia chaffeensis, dogs, epidemiology, Brazilian Northeastern region.

Article based on a Thesis submitted by the senior author in partial fulfillment of requirements for the Master's Degree. ${ }^{1}$ Programa de Pós-graduação em Ciência Animal (PPGCA), Universidade Estadual de Santa Cruz (UESC), Ilhéus, BA, Brazil. ${ }^{2}$ Faculdade de Medicina Veterinária, UESC, Ilhéus. ${ }^{3}$ Departamento de Ciências Agrárias e Ambientais (DCAA), UESC, Ilhéus. CORRESPONDENCE: T.V. Harvey [tatianivitor@ yahoo.com.br - Tel.: +55 (73) 99983-5097]. Hospital Veterinário (HV), Laboratório de Parasitologia Veterinária - UESC. Campus Soane Nazaré de Andrade. Rodovia Jorge Amado Km 16. Bairro Salobrinho. CEP 45662-900 Ilhéus, BA Brazil. 


\section{INTRODUCTION}

Canine babesiosis and ehrlichiosis are tick-borne parasitic disease caused by an intra-erythrocyte protozoan of the Babesia genus and a gram-negative intracellular bacteria of the Ehrlichia genus, respectively. The disease affects domestic and wild canids, and these become infected when bit by ticks [27,40]. E. chaffeensis is considered a zoonotic disease and no molecular diagnosis of dog infection has been reported in Brazil [27].

Babesiosis is an endemic disease in Brazil [7,10,11,25,33]. E. chaffeensis, in turn, has been reported in regions of the United States of America (USA), and is associated with the presence of vector Amblyomma americanum [16].

Babesiosis prevalence ranges from $0.97 \%$ [26] to $81.6 \%$ [13], depending on the locations, studied populations, and diagnostic tests chosen [35].

The most frequent clinical signs in dogs infected by Babesia spp. include pale mucous membranes, apathy, anorexia, fever, dehydration, weight loss, abdominal pain, and tenderness following kidney palpation $[6,18,20]$. Hematological changes such as normocytic hypochromic anemia, polychromasia, anisocytosis, neutrophilic leukocytosis, monocytosis, lymphopenia [20], leukopenia, pancytopenia [22], regenerative hemolytic anemia [12], and thrombocytopenia $[12,22,32]$. E. chaffeensis did not develop substancial clinical or hematologic abnormalities in dogs, but in human can lead to death. The dogs play a role as human reservoirs $[8,31]$.

Considering the lack of studies on these two related agents in the region, this study aimed to investigate the occurrence of infection from Babesia spp. and Ehrlichia chaffeensis in dogs from southeastern Bahia state, to determine, possible risk factors associated with the infection, and to identify the dogs' clinical and hematological manifestations. It's important elucidate that this is the first report of this agents in that region.

\section{MATERIALS AND METHODS}

\section{Studied Area}

A cross-sectional study was conducted in the municipality Ituberá (Figure 1), located in Southern Meso-region of Bahia, Micro-region of Valença $\left(13^{\circ} 43\right.$ S, $39^{\circ} 08 \mathrm{~W}$ ), inside the Atlantic Forest biome. The municipality has a total area of $417,274 \mathrm{Km}^{2}$, a total approximate population of 26,591 inhabitants, and a population density of 63.73 inhabitants $/ \mathrm{km}^{2}$ [21]. The region has a humid tropical climate, with an average temperature of $25.3^{\circ} \mathrm{C}$, an annual temperature range of $5.6^{\circ} \mathrm{C}$, and annual rainfall rates between 1,800 and $2,400 \mathrm{~mm}$, distributed throughout the year.

Animals

The study consisted of clinical examination of the canine population, blood sample collection and application of a structured questionnaire to dog owners. All households were visited in the nine investigated locals, which were Colônia, Índios, Pedreiras, Prainha, Santo André and Vila Itajaí, on the urban area, and Km 22, Lagoa Santa and Vila Itaberoê, on the rural area. The dogs were included in the study after their owners approved it. The sample size of the dog was calculated through Epi Info 3.5.3 software ${ }^{1}$, considering the size of Ituberá's dog population as $10 \%$ the human population in the municipality [9], a prevalence rate $50 \%$, a confidence interval of $95 \%$, and an error margin of $5 \%$. In all households only one dog was evaluated and the animal was selected by the owner.

\section{Collection of data and sample}

All dogs included in this study were evaluated for presence of ticks and clinical signs, such as anemia, anorexia, ocular and oral mucous membranes pallor, weight loss, diarrhea, vomiting, dehydration, lymphadenopathy and fever $[1,13,18,20,36]$. The data were entered in individual sheets. The information provided by the dog owners refers to occurrences during the month in which the investigation was carried out.

Additionally, the dog owners answered a structured questionnaire to determine the risk factors associated with the infection. The variables tick infestation, habitat, level of restriction, contact with other dogs, age, and sex were evaluated [10,19,33,34].

\section{Collection of biological samples}

Blood samples were taken from the dogs' ears, to prepare capillary blood smears. Furthermore, $5 \mathrm{~mL}$ peripheral venous blood was collected from each dog through their cephalic or jugular vein, and it was stored in tubes with and without EDTA.

\section{Hematological analysis}

The analyses were conducted in the State University of Santa Cruz's (UESC) Veterinary Hospital's Clinical Pathology Laboratory and Animal 
Genetics Laboratory. The samples in tubes without EDTA were used in serological analyses, whereas the ones with EDTA were used for hematologic analysis and later for molecular analysis. The hematological parameters evaluated were analyzed through a cell counter (ABC Vet ${ }^{\circledR}$ Automatic Blood Cell Counter) ${ }^{1}$. Anemia, leukocitosis, leukopenia, and thrombocytopenia $[2,20,22,23]$ were considered as babesiosis-related changes. Animals of hematocrit below $37 \%$ were considered as anemic, animals with platelet counts below $2 \times 10^{5} / \mathrm{mL}$ were considered thrombocytopenic, and the ones with global leukocyte counts below $7 \times 10^{3}$ / $\mathrm{mL}$ were considered leukopenic.

\section{Cytologic examination}

Capillary blood smears were prepared to identify intra-erythrocyte Babesia piroplasms. They were stained with Diff-Quick dye and analyzed in an optic microscope (Primo Star $^{\circledR}$ ZEISS) ${ }^{2}$ in a 100x objective lens (immersion).

\section{Detection of anti-Babesia canis antibodies}

Anti-Babesia canis antibodies were detected through IIFA, by using slides containing Babesia merozoites (Immunodot) ${ }^{3}$, control serum of previously known titrations, and anti-dog serum coupled with fluorescein isothiocyanate F-7887 ${ }^{\mathrm{TM}}$ (Sigma-Chemical) ${ }^{4}$. The initial dilution was 1:40 [10] and the positive samples were retested, albeit in two-fold serial dilutions until negative. The reading was conducted through a trinocular epi-fluorescence microscope (Olympus DP71) $)^{5}$ using a 40X objective lens. The serum samples of titrations equal to or greater than 1:40 were considered positive.

\section{DNA extraction and PCR}

After the hematological step, the blood sample was centrifuged (LS - 3 Plus $\left.^{\circledR}\right)^{6}$ at 1,650 $\mathrm{x} g$ for $10 \mathrm{~min}$, from where the leukocyte and blood cell layers were taken from; these were later identified and frozen at $-20^{\circ} \mathrm{C}$ until being processed. DNA from the total blood layer was extracted to conduct the PCR of Babesia, and DNA from the leukocyte layer was extracted to conduct the PCR for E. chaffeensis. The kit (Easy-DNA ${ }^{\circledR}$ kit) ${ }^{7}$ was used for both, as recommended by its manufacturer.

In order to amplify the rRNA $18 \mathrm{~S}$ gene of Babesia spp., we used primers Bab7 (5'-GGC TAC CAC ATC TAA GGA AG-3') and Bab9 (3'-CTA AGA ATT TCA CCT CTG ACA G-5') [15], which amplify a fragment with 490 base pairs.
The PCR mix was prepared for a final volume of $25 \mu \mathrm{L}$ [14], with the changes as follows: $1 \times$ PCR buffer; $2.5 \mathrm{mM}$ magnesium chloride; $0.2 \mathrm{mM}$ dNTP; $0.4 \mu \mathrm{M}$ Bab7 forward primer; $0.4 \mu \mathrm{M}$ Bab9 reverse primer, and 1.5 U Taq DNA polymerase ${ }^{7}$. Five $\mu \mathrm{L}$ of the DNA sample was used, once the quantification indicated a low DNA concentration in the samples. The amplification was performed in thermal cycler (Veriti ${ }^{\circledR}$ Thermal Cycler $)^{8}$ by using the following protocol: initial denaturation step at $94^{\circ} \mathrm{C}$ for $1 \mathrm{~min} ; 35$ cycles of denaturation at $94^{\circ} \mathrm{C}$ for $30 \mathrm{~s}$; annealing at $59^{\circ} \mathrm{C}$ for $30 \mathrm{~s}$, and extension at $72^{\circ} \mathrm{C}$ for $2 \mathrm{~min}$; and final extension at $72^{\circ} \mathrm{C}$ for $7 \mathrm{~min}$. The positive control slide was prepared from a Babesia canis isolate from a dog tested positive. Ultrapure water was used as a negative control. The amplicons ( $10 \mu \mathrm{L} / \mathrm{sample})$ were visualized through an ultraviolet transilluminator $\left(\text { L.PIX }^{\circledR}\right)^{9}$ in $2 \%$ agarose gel in 1x TAE buffer and photographed. The gels were stained with $0.1 \mu \mathrm{g} \cdot \mathrm{mL}^{-1}$ of SYBER $®$ Safe DNA Gel Stain7.

To amplify DNA from genus Ehrlichia, we used primers ECC (5-AGAACGAACGCTGGCGGCAAGC-3) and ECB (5- CGTATTACCGCGGCTGCTGGCA-3), which amplify part of the 16S rRNA gene from Ehrlichia spp. [4]. Later, to identify E. chaffeensis species, we used primers HE1 (5'-CAA TTG CTT ATA ACC TTT TGG TTA TAA AT-3') and HE3 (5' ${ }^{\prime}$-TAT AGG TAC CGT CAT TAT CTT CCC TAT- 3'), which amplify a fragment with 389 base pairs [4].

In order to calculate the PCR mix, we used 5 $\mu \mathrm{L}$ purified DNA, $0.4 \mathrm{mM}$ of each primer (ECC and ECB), $200 \mathrm{mM}$ of each dNTP, $5 \mathrm{mMMgCL} 2,1.6 \mathrm{x}$ PCR buffer ${ }^{7}$, and $2.5 \mathrm{U}_{\text {Taq DNA polymerase }}{ }^{7}$ and obtained a total final volume of $25 \mu \mathrm{L}$. The thermal cycler programming for identifying the genetic sequence of genus Ehrlichia spp. consisted of denaturation for 5 min at $94^{\circ} \mathrm{C}$, followed by 40 denaturation cycles at $94^{\circ} \mathrm{C}$ for $1 \mathrm{~min}$, annealing at $68^{\circ} \mathrm{C}$ for $1 \mathrm{~min}$ and $30 \mathrm{~s}$, and, finally, extension at $72^{\circ} \mathrm{C}$ for $2 \mathrm{~min}$. For the nested PCR, we used $1 \mu \mathrm{L}$ of the amplicon that resulted from the first PCR reaction, as well as $0.2 \mathrm{mM}$ of each HE1 and HE3 primer, to identify the genetic sequence of $E$. chaffeensis. The thermal cycler programming for the second reaction consisted of denaturation for $3 \mathrm{~min}$ at $94^{\circ} \mathrm{C}$, followed by 40 denaturation cycles at $94^{\circ} \mathrm{C}$ for $1 \mathrm{~min}$, annealing at $55^{\circ} \mathrm{C}$ for $1 \mathrm{~min}$ and $30 \mathrm{~s}$, and, finally, extension at $72^{\circ} \mathrm{C}$ for $1 \mathrm{~min}$ and $30 \mathrm{~s}$ [24]. The positive control was given by Prof. Rosângela Zacha- 
rias Machado, from "Júlio de Mesquita Filho" São Paulo State University, Jaboticabal campus. Ultrapure water was used as the negative control. The amplicons were visualized through an ultraviolet transilluminator $\left(\text { L.PIX }{ }^{\circledR}\right)^{9}$ in $2 \%$ agarose gel in $1 \times$ TAE buffer, and photographed. The gels were stained with $0.1 \mu \mathrm{g} \cdot \mathrm{mL}^{-1}$ of SYBER ${ }^{\circledR}$ Safe DNA Gel Stain ${ }^{7}$.

\section{Data Analysis}

The data were compiled and analyzed through Epi Inform software version 3.5.4 (CDC) ${ }^{10}$.

The association of infection from Babesia spp. with the clinical and hematological changes and the risk factors was verified through univariate analysis (Pearson's chi-squared test and Fisher's exact test) at a 5\% significance level, from a $95 \%$ confidence level. $T$ test was used to compare the hematocrit averages of infected and uninfected animals.

\section{RESULTS}

Among the 380 dogs evaluated, 326 (85.8\%) came from urban areas and $54(14.2 \%)$ came from rural areas, $237(62.4 \%)$ were males and $143(37.6 \%)$ were females, 265/380 dogs $(69.7 \%)$ were between 1-4 years old, $115 / 380$ dogs $(30.3 \%)$ were older than four years old and 115 (30.3\%) were infested by ticks.

In the cytologic analysis for diagnosing Babesia spp., intra-erythrocyte piroplasms were visualized in $2 / 380$ of the blood smears $(0.5 \%)$. Anti-B. canis antibodies were detected in 140/380 of the evaluated animal $(36.8 \%)$, at 1:40 dilution. In the subsequent dilutions, $1: 80$ and $1: 160,30$ positive dogs $(7.9 \%)$ and seven positive dogs $(1.8 \%)$ were respectively observed.

By PCR, 147/380 (38.7\%) dogs were detected positive by Babesia spp. (Figure 2), but no animals were tested positive for $E$. chaffeensis infection.

To perform the analysis of data from physical examinations and hematologic analyses were considered all positive dogs in at least one of the diagnostic tests used, totaling 223 dogs $(58.7 \%)$ infected by Babesia spp.

Among those 115 dogs infested by ticks, 68 dogs (30.5\%) were positive to Babesia spp. Among the 223 dogs infected by Babesia spp., 36 (16.1\%) were not observed to have clinical signs or hematological alterations. Clinical signs were only found in $14 \mathrm{dogs}$ (6.3\%), hematological alterations (thrombocytopenia, anemia, leukopenia and leukocytosis) were found in $105(47.1 \%)$ dogs, and 66 dogs (29.6\%) were observed to have clinical signs associated with one or more hematological alterations. Upon classifying the positive dogs in groups of symptomatic and asymptomatic animals, we observed that $80 / 223$ dogs (35.8\%) had clinical signs that were either associated or not with hematological alterations, and that 141/223 (63.2\%) of the dogs were asymptomatic. Among the 223 dogs positive for Babesia spp., 16/223 (7.2\%) were dehydrated, 13/223 (5.8\%) had diarrhea, 19/223 (8.5\%) were vomiting, and 53/223 (23.7\%) were found to have lymphadenopathy. However, no clinical signs were found to be significant for the infection.

We observed hematological abnormalities (either associated or not with clinical signs) in 171/223 (76.7\%) of the infected dogs. Among these changes, we found that $113 / 223(50.6 \%)$ dogs were thrombocytopenic, 78/223 (34.9\%) were anemic, 60/223 (26.9\%) had leukocitosis, and 12/223 (5.4\%) dogs had leukopenia. The infected $(\mathrm{Ht}=40 \%)$ and uninfected dogs' $(\mathrm{Ht}=39 \%)$ hematocrit averages were not found to significantly differ $(P=0.47)$. No hematological changes were found to be significant for the disease.

Variables sex, habitat (urban or rural), exposure to other dogs, age, and infestation by ticks were not found to be risk factors. The variable "level of restriction" was established to evaluate whether longer exposure to vectors was a risk factor in this condition. Among the positive animals, 175/223 (78.4\%) were semi-restricted, and this is a risk factor for the infection $(P=0.01)$ [Table 1].

\section{DISCUSSION}

The absence of infection by Ehrlichia chaffeensis in our study corroborates the literature, which currently mentions the inexistent description of Brazilian dogs that are positive to the agent by molecular diagnosis [17].

The underdetection of babesiosis from blood smears $(0.5 \%)$ was inferior to the lowest prevalences found in Brazil, which are described in previous studies [7,15,33], which found the presence of Babesia merozoites in $2.2 \%, 3.9 \%$, and $3.3 \%$, respectively. Low infection prevalence in the cytologic analysis associated with high seroprevalence, as in this study, are characteristics of chronic or subclinical infections [3].

The high seroprevalence rate by IFAT observed in this study was also found in Minas Gerais state, where $28.7 \%$ of the dogs evaluated were seropositive [10]. 
T.V. Harvey, J.F. Veloso, M.R. Santos, et al. 2017. Babesia spp. and Ehrlichia chaffeensis infection in Dogs from Southeastern Bahia, Brazil.

Table 1. Bivariate analysis of the factors associated with infection by Babesia spp. in dogs from southeastern Bahia, Brazil.

\begin{tabular}{|c|c|c|c|c|c|c|}
\hline Variable & & $\mathrm{N}$ & $\mathrm{n}(\%)$ Infected & $P$ Value & OR & $95 \%$ IC \\
\hline \multirow{2}{*}{ Age Range } & $1-4$ years & 265 & $155(58.5)$ & 0.99 & 0.97 & $0.62-1.52$ \\
\hline & $>4$ years & 115 & $68(59.1)$ & & & \\
\hline \multirow{2}{*}{$\begin{array}{l}\text { Contact with } \\
\text { other dogs }\end{array}$} & Yes & 279 & $163(58.4)$ & 0.95 & 0.96 & $0.60-1.52$ \\
\hline & No & 101 & $60(59.4)$ & & & \\
\hline \multirow{3}{*}{ Infestation by ticks } & Yes & 115 & $68(59.1)$ & 0.99 & 0.97 & $0.62-1.52$ \\
\hline & No & 265 & $155(58.5)$ & & & \\
\hline & Restrict & 99 & $48(48.5)$ & $0.02 *$ & 1.75 & $1.10-2.78$ \\
\hline Level of restriction & $\begin{array}{l}\text { Semi-re- } \\
\text { stricted }\end{array}$ & 281 & $175(62.3)$ & & & \\
\hline \multirow{2}{*}{ Location } & Urban & 326 & $195(59.8)$ & 0.34 & 1.38 & $0.77-2.46$ \\
\hline & Rural & 54 & $28(51.9)$ & & & \\
\hline \multirow{2}{*}{ Sex } & $\mathrm{F}$ & 143 & $85(59.4)$ & 0.95 & 0.90 & $0.62-1.45$ \\
\hline & M & 237 & $138(58.2)$ & & & \\
\hline
\end{tabular}

$\mathrm{N}=$ number of animals, $\mathrm{OR}=$ odds ratio, $\mathrm{F}=$ female, $\mathrm{M}=$ male, $(*)$ Significant difference $P<0.05$.

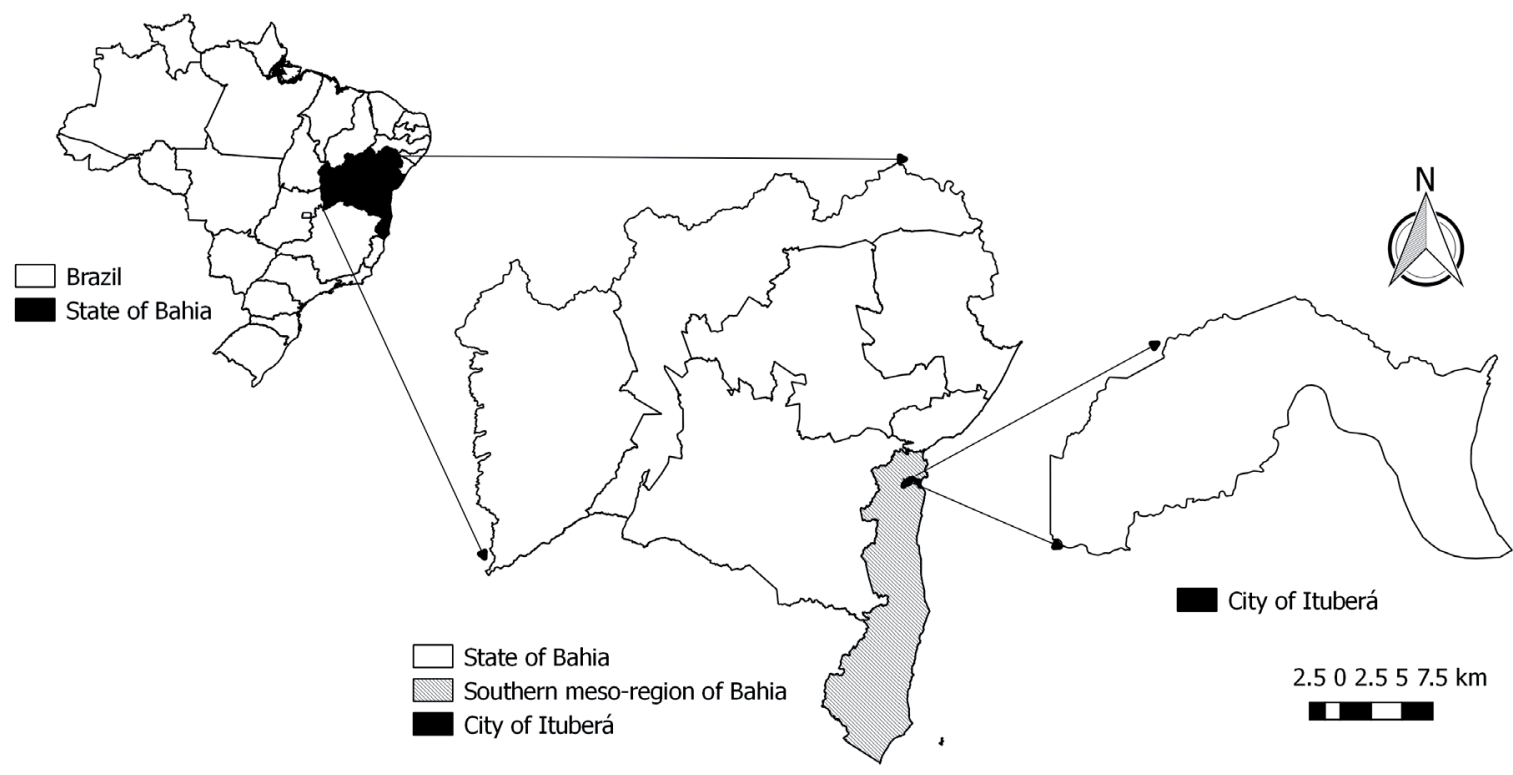

Figure 1. Location map of the municipality of Ituberá.

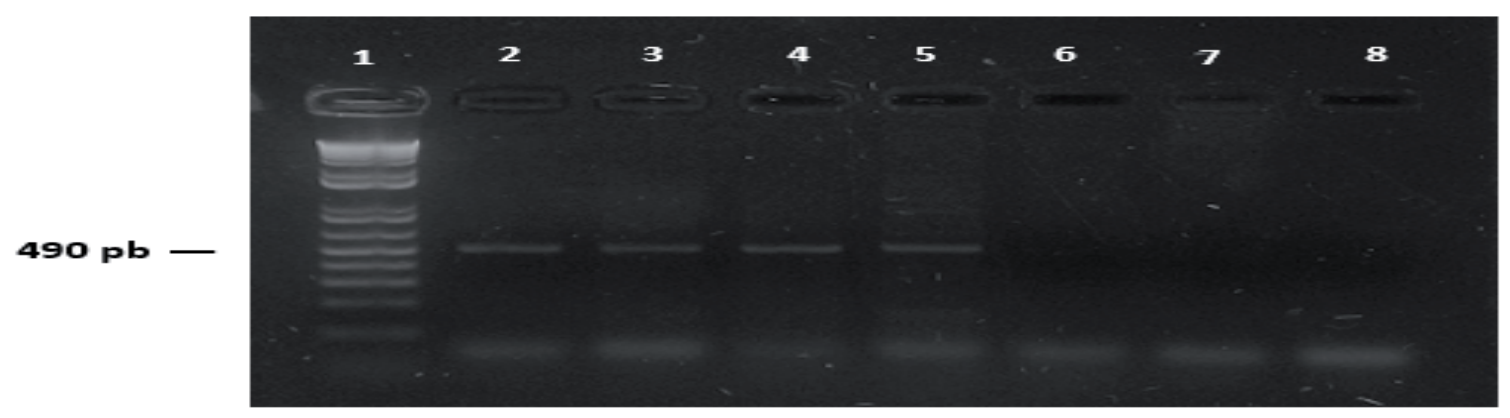

Figure 2. Detection of Babesia spp. through PCR. Amplification of a region of $490 \mathrm{bp}$, regarding 18S rRNA gene, conducted with Bab7 and Bab9 primers. Line 1: $1 \mathrm{~kb}$ Plus DNA Ladder Molecular Marker. Line 2: positive control. Lines 3 to 5: blood samples positive for Babesia spp. Lines 6 and 7: negative samples. Line 8: negative control. 
Higher rates were also found with $73.3 \%$ seropositive dogs among dogs treated in nine veterinary clinics from Minas Gerais, with clinical signs that matched infection from Babesia spp. [19]. This population differs from the one investigated in this study, in which dogs were selected regardless of clinical complaints, which justifies a lower rate in the serologic analysis. High seroprevalence rates may also indicate chronicity and/or subclinical disease when associated with low parasitemia. Such condition may also be indicated by the low title variation observed (1:40 - 1:160), which is commonly found four to five months after the infection [39].

In this study, $75 / 140(53,6 \%)$ of the dogs tested positive for Babesia by serology tested negative in the PCR, which suggests these dogs had previously been exposed to this pathogen and maintained detectable levels of antibodies, or that they were subclinical or chronic carriers of the infection. Such observation indicates that the associated use of serological and molecular techniques may be useful in the identification of positive animals in the subclinical or chronic forms of the disease, as found in this study. Besides that, the high number of positive dogs following PCR demonstrates that this method was an important tool for detecting the disease in asymptomatic dogs.

The fact that a high number of positive and asymptomatic dogs were observed in this study suggests the presence of subclinical or chronic forms of the disease in the studied population, which is characteristic of endemic areas [3]. This is the predominant infection form in Brazil [40]. Also, most animals that carry the subclinical or chronic form of the disease may appear seemingly healthy [35]. Furthermore, the latent phase of the infection results in a small number of hyperacute and acute cases, as observed in this study as well. Besides that, the equal hematocrit averages of dogs either carrying or not the disease suggests that the infected animals, especially the seemingly healthy dogs, are subclinical or chronic carriers - either asymptomatic or otherwise - that are adapted to the disease, which may contribute to the agent remaining in this population. Besides that, the fact that no clinical sign of hematological change was significant for the infection may demonstrate the low pathogenicity of this agent in the evaluated population.

During the collection of samples, we observed that all urban neighborhoods in the municipality had rural characteristics, including the presence of vegetable gardens and/or farm animal pens. In this case, the high infection prevalence may be related to the rural profile of the municipality, as also observed in previous studies with dogs from Brazilian rural communities [10,29,33].

In this study, the variables sex, age, infestation by ticks, habitat, and exposure to other dogs were not found to be risk factors. Such observation corroborates the data from other studies conducted in the country $[10,19,28,30,33,34,37,38]$. In regards to the age variable, our results disagreed with the results in literature $[10,12,37]$, whose state that seroprevalence is higher in adult animals. The mismatched information regarding age variable points, towards a need for more detailed studies to clarify whether this variable is associated with infection from Babesia spp.

The majority of the dogs in this study had a low level of restriction and it was hence classified semi-restricted dogs. This condition was considered a risk factor $(P=0.01)$ and is probably due to the increased exposure of these animals to canine babesiosis vectors, once these dogs moved freely through different neighborhood areas and villages in the municipality.

\section{CONCLUSIONS}

Infection from Babesia spp. is present in southeastern Bahia's canine population, and it mainly manifests itself in the subclinical form. In Ituberá, raising dogs in a semi-restricted ways constitutes a risk factor for the infection. Combining diagnostic methods is important to identify the infection and determine its prevalence in epidemiological studies. PCR was fundamental in this study, to identify the infection in asymptomatic dogs.

Despite no animals having been diagnosed with infection by Ehrlichia chaffeensis, studies must be conducted to identify this bacterium due to its zoonotic potential, by establishing effective diagnostic methods and active surveillance for the disease, as it can arise in an emerging way.

\section{MANUFACTURERS}

${ }^{1}$ Horiba Instruments Brasil Ltda. Jundiaí, SP, Brazil.

${ }^{2}$ Carl Zeiss. Oberkochen, Germany.

${ }^{3}$ Immunodot Industria Pesquisa Produtos para Diagnósticos Ltda. Jaboticabal, SP, Brazil.

${ }^{4}$ Sigma-Aldrich Co. Saint Louis, MO, USA.

${ }^{5}$ Olympus Optical do Brasil Ltda. São Paulo, SP, Brazil.

${ }^{6} \mathrm{CELM}$ - Companhia Equipadora de Laboratórios Modernos. São Paulo, SP, Brazil. 
T.V. Harvey, J.F. Veloso, M.R. Santos, et al. 2017. Babesia spp. and Ehrlichia chaffeensis infection in Dogs from

${ }^{7}$ Invitrogen Corporation. Carlsbad, CA, USA.

${ }^{8}$ Applied Biosystems. Foster City, CA, USA.

${ }^{9}$ Loccus Biotecnologia - Loccus Do Brasil Ltda. São Paulo, SP, Brazil.

${ }^{10}$ Centers for Disease Control and Prevention (CDC). Atlanta, GA, USA.

Funding. This research was supported by Coordenação de Aperfeiçoamento de Pessoal de Nível Superior - CAPES (Coordination for the Improvement of Undergraduate Personnel), Fundação de Amparo à Pesquisa do Estado da Bahia - FAPESB (Bahia State Research Support Foundation) and the State University of Santa Cruz (UESC).
Acknowledgments. We would like to thank to Prof. Rosângela Zacharias Machado, from “Júlio de Mesquita Filho" São Paulo State University, Jaboticabal Campus, for providing us with positive controls for Erlichia chaffeensis.

Ethical approval. This study was approved by the Ethics Committee for the Use of Animals of the State University of Santa Cruz (protocol n. 028/2012).

Declaration of interest. The authors report no conflicts of interest. The authors alone are responsible for the content and writing of paper.

\section{REFERENCES}

1 Abd Rani P.A.M., Irwin P.J., Coleman G.T., Gatne M. \& Traub R. 2011. A survey of canine tick-borne diseases in India. Parasites and Vectors. 4: 141

2 Abdullahi S.U., Mohammed A.A., Trimnel A.R., Sannusi A. \& Alafiatayo R. 1990. Clinical and haematological findings in 70 naturally occurring cases of canine babesiosis. Journal of Small Animal Practice. 31(3): 145-147.

3 Almosny N.R.P., Massard C.L., Labarthe N.V., O’Dwyer L.H., Souza A.M., Alves L.C. \& Serrão M.L. 2002. Hemoparasitoses em Pequenos Animais Domésticos e como Zoonoses. Rio de Janeiro: L.F. Livros, 135p.

4 Anderson B.E., Sumner J.W., Dawson J.E., Tzianabos T., Greene C.R., Olson J.G., Fishbein D.B., Olsen-Rasmussen M., Holloway B.P., George E.H. \& Azad A.F. 1992. Detection of the Etiologic Agent of Human Ehrlichiosis by Polymerase Chain Reaction. Clinical Microbiology and Infection. 30(4): 775-780.

5 Araújo A.C., Silveira J.A.G., Azevedo S.S., Nieri-Bastos F.A., Ribeiro M.F.B., Labruna M. B. \& Horta M.C. 2015. Babesia canis vogeli infection in dogs and ticks in the semiarid region of Pernambuco, Brazil. Pesquisa Veterinária Brasileira. 35(5): 456-461.

6 Bastos C.V., Moreira S.M. \& Passos L.M.F. 2004. Retrospective study (1998-2001) on canine babesiosis in Belo Horizonte, Minas Gerais State, Brazil. Annals of the New York Academy of Sciences. 1026(1): 158-160.

7 Braga J.F.V. 2011. Babesiose canina em Teresina, Piauí. 60f. Dissertação (Mestrado em Ciência Animal) - Faculdade de Medicina Veterinária, Universidade Federal do Piauí.

8 Breitschwerdt E.B. 1990. Babesiosis. In: Greene C.E. (Ed). Infectious diseases of dog and cat. Philadelphia: W.B. Saunders Co., pp.796-803.

9 Cifuentes E.E. 1988. Program for the elimination of urban rabies in Latin America. Reviews of Infectious Diseases. 10: 689-692.

10 Costa-Júnior L.M., Ribeiro M.F.B., Rembeck K., Rabelo E.M.L., Zahler-Rinder M., Hirzmann J., Pfister K. \& Passos L.M.F. 2009. Canine babesiosis caused by Babesia canis vogeli in rural areas of the State of Minas Gerais, Brazil and factors associated with its seroprevalence. Research in Veterinary Science. 86(2): 257-260.

11 Dantas-Torres F. 2008. Canine vector-borne diseases in Brasil. Parasite and Vectors. 1: 25.

12 Dantas-Torres F. \& Figueredo L.A. 2006. Canine babesiosis: A Brazilian perspective. Veterinary Parasitology. 148(34): 197-203.

13 De Sousa K.C.M., André M.R., Herrere H.M., De Andrade G.B., Jusi M.M.G., Dos Santos L.L., Barreto W.T.G., Machado R.Z. \& De Oliveira G.P. 2013. Molecular and serological detection of tick-borne pathogens in dogs from an area endemic for Leishmania infantum in MatoGrosso do Sul, Brazil. Revista Brasileira de Parasitologia Veterinária. 22(4): 525-531.

14 Duarte S.C., Linhares G.F.C., Romanowski T.N., Silveira Neto O.J. \& Borges L.M.F. 2008. Assessment of primers designed for the subspecies-specific discrimination among Babesia canis canis, Babesia canis vogeli and Babesia canis rossi by PCR assay. Veterinary Parasitology. 152(1-2): 16-20.

15 Duarte S.C., Parente J.A., Pereira M., Soares C.M.A. \& Linhares G.F.C. 2011. Phylogenetic characterization of Babesia canis vogeli in dogs in the state of Goiás, Brazil. Revista Brasileira de Parasitologia Veterinária. 20(4): 274-280. 
16 Eng T.R., Fishbein D.B., Dawson J.E., Greene C.R. \& Redus M. 1990. Surveillance of human erhlichiosis in the United States. Annals of the New York Academy of Sciences. 590: 306-307.

17 Galvão M.A.M., Lamounier J.A., Bonono E., Tropia M.S., Rezende E.G., Calic S.B., Chamone C.B., Machado M.C., Otoni M.E.A., Leite R.C., Caram C., Mafra C.L. \& Walker. D.H. 2002. Emerging and reemerging rickettsiosis in an endemic area of Minas Gerais State, Brazil. Cadernos de Saúde Pública. 18(6): 1593-1597.

18 Guimarães A.M., Oliveira T.M.F.S. \& Santa-Rosa I.C.A. 2002. Babesiose canina: uma visão dos clínicos veterinários de Minas Gerais. Clínica Veterinária. 41: 60-68.

19 Guimarães A.M., Rocha C.M.B.M., Oliveira T.M.F.S., Rosado I.R., Morais L.G. \& Santos R.R.D. 2009. Fatores associados à soropositividade para Babesia, Toxoplasma, Neospora e Leishmania em cães atendidos em nove clínicas veterinárias do município de Lavras, MG. Revista Brasileira de Parasitologia Veterinária. 18(E-Suppl. 1): 49-53.

20 Guimarães J.C., Albernaz A.P., Machado J.A., Junior O.A.M. \& Garcia L.N.N. 2004. Aspectos clínico-laboratoriais da babesiose canina na cidade de Campos dos Goytacazes, RJ. Revista Brasileira de Parasitologia Veterinária. 13: 229.

21 Instituto Brasileir de Geografia e Estatística (IBGE). 2010. Censo Demográfico 2010. Available at <http://cod.ibge. gov.br/W1P> [Acessed in July 2013].

22 Jojima F.S., Garcia J.L., Vidotto M.C., Balarin M.R.S., Fabretti A.K., Gasparini M.R., Coelho A.L.M. \& Vidotto O. 2008. Ocorrência e caracterização molecular de espécies de Babesia em cães de uma população hospitalar da região de Londrina, PR. Revista Brasileira de Parasitologia Veterinária. 17(E-Suppl.1): 277-283.

23 Kettner F., Reyers F. \& Miller D. 2003. Thrombocytopenia in canine babesiosis and its clinical usefulness. Journal of the South African Veterinary Association. 74(3): 63-68.

24 Kocan A., Levesque G.C., Whitworth L.C., Murphy G.L., Ewing S.A. \& Barker R.W. 2000. Naturally Occurring Ehrlichia chaffeensis Infection in Coyotes from Oklahoma. Emerging Infectious. Diseases Journal. 6(5): 477-480.

25 Labruna M.B. \& Campos Pereira M. 2001. Carrapato em cães no Brasil. Clínica Veterinária. 30: 24-32.

26 Lemos T.D., Cerqueira A.M.F., Toma H.K., Silva A.V., Corrêa R.G.B., Paludo G.R., Massard C.L. \& Almosny N.R.P. 2012. Detection and molecular characterization of piroplasms species from naturally infected dogs in southeast Brazil. Revista Brasileira de Parasitologia Veterinária. 21(2): 137-142.

27 Machado R.Z., Duarte J.M., Dagnone A.S. \& Szabó M.P. 2006. Detection of Ehrlichia chaffeensis in Brazilian marsh deer (Blastocerus dichotomus). Veterinary Parasitology. 139(1-3): 262-266.

28 Maia M.G., Costa R.T., Haddad J.P.A., Passos L.M.F. \& Ribeiro M.F.B. 2007. Epidemiological aspects of canine babesiosis in the semiarid area of the state of Minas Gerais, Brazil. Preventive Veterinary Medicine. 79(2-4): 155-162.

29 O'dwyer L.H., Lopes V.V.A., Rubini A.S., Paduan K.S. \& Ribolla P.E.M. 2009. Babesia spp. infection in dogs from rural areas of São Paulo state, Brazil. Revista Brasileira de Parasitologia Veterinária. 18(2): 23-26.

30 Ribeiro M.F.B., Passos L.M.F. \& Lima J.D. 1990. Freqüência de anticorpos fluorescentes anti-Babesia canis em cães em Belo Horizonte, Minas Gerais. Arquivo Brasileiro de Medicina Veterinária e Zootecnia. 42(6): 511-517.

31 Rojas A., Rojas D., Montenegro V., Gutiérrez R., Yasur-Landau D. \& Baneth G. 2014. Vector-borne pathogens in dogs from Costa Rica: First molecular description of Babesia vogeli and Hepatozoon canis infections with a high prevalence of monocytic ehrlichiosis and the manifestations of co-infection. Veterinary Parasitology. 199(3-4): 121-128.

32 Santos F., Coppede J.S., Pereira A.L.A., Oliveira L.P., Roberto P.G., Benedetti R.B.R., Zucoloto L.B., Lucas F., Sobreira L. \& Martins M. 2009. Molecular evaluation of the incidence of Ehrlichia canis, Anaplasma platys and Babesia spp. in dogs from Ribeirão Preto, Brazil. The Veterinary Journal. 179(1): 145-148.

33 Silva A.B., Costa A.P., De Sá J.C., Costa F.B., Dos Santos A.C.G. \& Guerra R.M.S.N.C. 2012. Detecção molecular de Babesia canis vogeli em cães e em Rhipicephalus sanguineus na mesorregião do oeste maranhense, nordeste brasileiro. Ciência Animal Brasileira. 13(3): 388-395.

34 Silva M.C.A., Mundim A.V., Mendonça G.A., Mundim M.J.S. \& Guimarães E.C. 2014. Hemoparasitos em cães domésticos naturalmente infectados, provenientes das zonas urbana e rural do município de Abadia dos Dourados, Minas Gerais, Brasil. Bioscience Journal. 30(5): 892-900.

35 Taboada J. 1998. Babesiosis. In: Greene C.E. (Ed). Infectious diseases of the dog and cat. 2nd edn. Philadelphia: W.B. Saunders Co., pp.473-481.

36 Trapp S.M., MoraisH.S.A. \& Vidotto O. 2004. Babesiose canina. Medvep - Revista Científica de Medicina Veterinária - pequenos animais e animais de estimação. 2(7): 211-217. 
T.V. Harvey, J.F. Veloso, M.R. Santos, et al. 2017. Babesia spp. and Ehrlichia chaffeensis infection in Dogs from Southeastern Bahia, Brazil. Acta Scientiae Veterinariae. 45: 1457.

37 Trapp S.M., Messick J.B., Vidotto O., Jojima F.S. \& Morais H.S.M. 2006. Babesia gibsoni genotype Asia in dogs from Brazil. Veterinary Parasitology. 141(1-2): 177-180.

38 Ungar De Sá M.F.M., Ungar De Sá J.E., Bittencourt D.V.V., Bispo A.C., Régis A.M.M., Souza Filho N.J., Gomes Neto C.M.B., Souza B.M.P.S., Bittencourt T.C.C. \& Franke C.R. 2007. Estudo retrospectivo (1991-2005), dos casos de babesiose canina na cidade de Salvador e Região Metropolitana, Bahia. Revista Brasileira de Saúde e Produção Animal. 8(3): 178-183.

39 Vercammen F., De Deken R. \& Maes L. 1997. Duration of protective immunity in experimental canine babesiosis after homologous and heterologous challenge. Veterinary Parasitology. 68(1-2): 51-55.

40 Vidotto O. \& Trapp S.M. 2004. Babesiose canina. Revista Brasileira de Medicina Veterinária. 13(E-Suppl.1): 58-61. 